\title{
Terapi Bekam Terhadap Penurunan Tekanan Darah
}

\author{
Hanina Amaliyah ${ }^{1}$, Yeni Koto ${ }^{2}$ \\ ${ }^{1,2}$ Program Sarjana Keperawatan \\ Sekolah Tinggi Ilmu Keseahatan Indonesia Maju \\ Jln. Harapan Nomor 50, Lenteng Agung- Jakarta Selatan 12610 \\ Telp: (021) 78894045, Email: ${ }^{1}$ amaliyahnina@ gmail.com, ${ }^{2}$ kyoto.yeni@gmail.com
}

\begin{abstract}
Abstrak
Hipertensi adalah suatu keadaan ketika tekanan darah di pembuluh darah meningkat secara kronis. Salah satu terapi komplementer yang dilakukan dalam penanganan hipertensi yaitu terapi bekam. Bekam (AlHijamah) merupakan metode pengobatan dengan cara mengeluarkan darah kotor dari dalam tubuh melalui permukaan kulit. Tujuan penelitian ini untuk mengetahui tentang pengaruh terapi bekam terhadap penurunan tekanan darah pada pasien hipertensi. Desain penelitian menggunakan pre eksperimental dengan model one group pretest-posttest. Populasi penelitian ini adalah pasien hipertensi yang berbekam di Bekam Ruqyah Center Pasar Minggu sebanyak 64 orang. Teknik pengambilan sampel menggunakan purposive sampling dengan sampel 38 responden. Hasil dari uji Wilcoxon didapatkan nilai $p$ value 0,000. Hal ini menunjukkan bahwa terapi bekam dapat menurunkan tekanan darah pada pasien hipertensi. Diharapkan bagi masyarakat dan dunia medis dapat menggunakan terapi bekam sebagai salah satu terapi komplementer dalam mengatasi hipertensi.
\end{abstract}

Kata kunci : Hipertensi, terapi bekam

\section{Abstract}

Hypertension is a condition when blood pressure in blood vessels increases chronically. One of the complementary therapies performed in the treatment of hypertension is cupping therapy. Cupping (AlHijamah) is a method of treatment by removing dirty blood from the body through the skin surface. The purpose of this research to determine about the effect of cupping therapy on the decrease in blood pressure in hypertensive patients. Design using pre-experimental research design model with one group pretestposttest. The study population was patients with hypertension who used cupping in Bekam Ruqyah Center Pasar Mingggu as many as 64 people. The sampling technique used purposive sampling with a sample of 38 respondents. Results of the Wilcoxon test $p$ value 0,000. This suggests that cupping therapy can lower blood pressure in hypertensive patients. Expected for the public and the medical world can use cupping therapy as a complementary therapy to treat hypertension.

Keywords : : Hypertension, cupping therapy 



\section{Pendahuluan}

Penyakit tidak menular merupakan penyakit kronis yang tidak ditularkan dari orang ke orang. Data penyakit tidak menular meliputi: (1) asma; (2) penyakit paru obstruksi kronis; (3) kanker; (4) diabetes melitus; (5) hipertiroid; (6) hipertensi; (7) jantung koroner; (8) gagal jantung; (9) stroke; (10) gagal ginjal kronis; (11) batu ginjal; (12) penyakit sendi atau rematik. Penyakit tidak menular, terutama hipertensi terjadi penurunan dari 31,7 persen tahun 2007 menjadi 25,8 persen tahun $2013 .{ }^{1}$ Asumsi terjadi penurunan bisa bermacammacam mulai dari alat pengukur tensi yang berbeda sampai pada kemungkinan masyarakat sudah mulai datang berobat ke fasilitas kesehatan. Penyakit tekanan darah tinggi merupakan faktor resiko utama dari perkembangan penyakit jantung dan stroke. Penyakit hipertensi juga disebut sebagai "the silent diseases" karena tidak terdapat tandatanda atau gejala yang dapat dilihat dari luar. Penyakit hipertensi berkembang secara perlahan, tetapi secara potensial sangat berbahaya. $^{2}$

Hipertensi adalah suatu keadaan ketika tekanan darah di pembuluh darah meningkat secara kronis. Hal tersebut dapat terjadi karena jantung bekerja lebih keras memompa darah untuk memenuhi kebuthan oksigen dan nutrisi tubuh. Jika dibiarkan, penyakit ini dapat mengganggu fungsi organ-organ lain, terutama organ lain, terutama organ-organ vital seperti jantung dan ginjal. ${ }^{2}$ Hipertensi dapat menyebabkan komplikasi yang berbahaya jika tidak ditangani dengan baik. Komplikasi hipertensi diantaranya berupa gangguan pada otak, sistem kardiovaskuler, ginjal dan mata. Hipertensi yang terjadi dalam jangka waktu lama dapat menyebabkan stroke, serangan jantung, gagal jantung dan merupakan penyebab utama gagal ginjal kronik. ${ }^{3}$ Dalam penelitian yang dilakukan oleh purnama (2017) menyatakan bahwa stress memiliki pengaruh yang signifikan terhadap terjadinya peningkatan tekanan darah tinggi. ${ }^{12}$

Akhir-akhir ini banyak orang menyukai pengobatan komplementer, beberapa alasan diantaranya: biaya terjangkau, tidak menggunakan bahan-bahan kimia dan efek penyembuhan cukup signifikan dan salah satu pengobatan komplementer yang dapat menangani hipertensi yaitu terapi bekam. ${ }^{4}$ Bekam adalah sebuah metode penanganan penyakit yang melibatkan energi dan darah ke permukaan kulit menggunakan ruang hampa udara (vakum) yang tercipta di dalam mangkuk seperti gelas atau bambu. Ustadz Suhardi menjelaskan bekam merupakan metode pengobatan dengan penyedotan kulit di bagian-bagian tertentu untuk mengeluarkan racun dan oksidan dalam tubuh melalui torehan tipis yang mengenai pembuluh darah kapiler pada epidermis. Dokter Umar dalam bukunya "Sembuh dengan Satu Titik" mengatakan, bekam adalah metode pengobatan dengan metode tabung atau gelas yang ditelungkupkan pada permukaan kulit agar menimbulkan bendungan lokal. Terjadinya bendungan lokal disebabkan tekanan negatif dalam tabung yang sebelumnya benda-benda dibakar dan dimasukan kedalam tabung agar terjadi pengumpulan darah lokal. Kemudian darah yang telah berkumpul dikeluarkan dari kulit dengan dihisap. ${ }^{4}$ Efek bekam terhadap darah diantaranya: Bekam menstimulasi darah ditubuh secara umum melalui zat nitrit oksida (NO) yang berperan meluaskan pembuluh darah, bekam berperan mengurangi darah dan cairan yang menyertai proses peradangan dengan cara mengeluarkan cairan-cairan ini dari celah-celah antarsel. Begitu pula zat-zat pemicu peradangan juga ikut dikeluarkan, misalnya zat histamine, bekam juga berperan meningkatkan jumlah sel darah merah, meningkatkan jumlah sel darah putih, mengubah darah yang terlalu asam menjadi proporsional, membersihkan darah sebagaimana dikatakan oleh Dr. Katashi, dosen di Universitas Osaka. ${ }^{5}$

Berdasarkan studi pendahuluan yang dilakukan oleh peneliti pada 8 Agustus 2016 di Bekam Ruqyah Center, dengan mewawancarai 4 petugas bekam dengan 1 orang kepala cabang BRC didapatkan hasil bahwa keluhan terbanyak yang datang ke BRC pasar minggu adalah pasien dengan keluhan pusing, memiliki riwayat hipertensi dan bahkan disertai dengan stroke. Setelah dilakukannya pengobatan terapi bekam, keesokan harinya pasien di tensi kembali oleh petugas dan hasil tekanan darah yang didapat pasien hipertensi adalah awal sebelum di bekam TD mencapai 200/90 mmHg, kemudian setelah di bekam turun menjadi 130/80 mmHg. Dan testimoni yang dikatakan pasien kepada petugas BRC mengatakan bahwa mereka merasa lebih enakan setelah di bekam. Dari wawancara peneliti dengan kepala cabang BRC pasar minggu mengatakan bahwa alasan terbanyak pasien hipertensi memilih terapi bekam ini 
karena biaya obat hipertensi yang mahal, pasien yang malas untuk minum obat dokter serta atas saran dari keluarga pasien untuk melakukan terapi bekam. Pada tanggal 10 Agustus 2016 peneliti melakukan wawancara kepada 3 pasien bekam di klinik bekam ruqyah center wilayah pasar minggu Jakarta selatan dari 3 pasien bekam mengatakan bahwa mereka memilih bekam karena mereka di rekomendasikan oleh teman kantor mereka, dari keluarganya yang sudah merasakan di bekam dan mereka mengatakan saat setelah di lakukan bekam mereka merasa badannya enakan dan lebih enteng, pusing-pusing nya berkurang bahkan hilang setelah di lakukan bekam. Tujuan pada penelitian ini adalah untuk mencari ada atau tidaknya pengaruh terapi bekam terhadap penurunan tekanan darah pada pasien hipertensi.

\section{Metode}

Penelitian ini merupakan penelitian kuantitatif, menggunakan pre experimental design dengan one group pretest-posttest design. Penelitian ini dilakukan dengan cara memberikan pretest (pengamatan awal) terlebih dahulu sebelum diberikan intervensi, setelah itu diberikan intervensi, kemudian dilakukan kembali posttest (pengamatan akhir). ${ }^{6}$ desain ini digunakan untuk mengetahui pengaruh terapi bekam terhadap penurunan tekanan darah pada pasien hipertensi di klinik BRC pasar minggu. Waktu penelitian dimulai dari Oktober - Desember 2016.

Populasi merupakan keseluruhan dari objek penelitian atau objek yang akan di teliti. ${ }^{7}$ Pada penelitian ini sebanyak 64 responden, dan berdasarkan hasil penghitungan sampel di dapatkan sampel sebanyak 38 responden yang merupakan pasien hipertensi yang berbekam di Klinik BRC pasar minggu. Teknik pengambilan sampel pada penelitian ini menggunakan purposive sampling yaitu yang didasarkan pada suatu pertimbangan tertentu yang dibuat oleh peneliti sendiri, berdasarkan ciri atau sifat-sifat populasi yang sudah diketahui sebelumnya. $^{7}$

Analisa data diartikan sebagai upaya data yang sudah tersedia kemudian diolah dengan statistic dan dapat digunakan untuk menjawab rumusan masalah dalam penelitian. ${ }^{7}$ analisis data yang digunakan pada penelitian ini antara lain analisis univariat dan bivariate. Analisis univariat digunakan untuk dua tujuan, yaitu pertama analisis deskriptif variabel penelitian, dilakukan untuk menggambarkan setiap variabel yang diteliti secara terpisah dengan cara membuat tabel frekuensi dari masingmasing variabel.

Analisis bivariate dilakukan terhadap dua variabel yang diduga berhubungan atau berkorelasi. Dalam penelitian ini menggunakan uji Wilcoxon. Uji tersebut digunakan untuk mengetahui pengaruh sebelum dan sesudah diberikan terapi bekam terhadap penurunan tekanan darah pada pasien hipertensi. Interpretasi dari uji Wilcoxon yaitu dengan menggunakan taraf signifikan $(\alpha=0,05)$. Kaidah keputusan analisa datanya yaitu apabila $p$ value $>0,05$ maka Ho diterima artinya tidak ada pengaruh terapi bekam terhadap penurunan tekanan darah pada pasien hipertensi dan sebaliknya bil $p$ value < 0,05 maka Ho ditolak artinya ada pegaruh terapi bekam terhadap penurunan tekanan darah pada pasien hipertensi.

\section{Hasil}

\section{Analisis Univariat}

Tabel 1. Distribusi karakeristik usia responden di Klinik BRC Pasar Minggu Jakarta tahun 2016.

\begin{tabular}{ccc}
\hline Usia & Frekuensi & Persen (\%) \\
\hline $30-39$ & 12 & 31,5 \\
$40-49$ & 14 & 36,8 \\
$50-59$ & 8 & 21 \\
$60-69$ & 4 & 10,5 \\
\hline Total & 38 & 100 \\
\hline
\end{tabular}

Berdasarkan tabel diatas dapat kita simpulan bahwa usia responden di Klinik BRC Pasar Minggu didapatkan bahwa rentang usia 30-39 tahun sebanyak 12 orang (31.5\%), usia 40-49 tahun sebanyak 14 orang (36.8\%), usia dengan rentang 50-59 tahun sebanyak 8 orang (21\%), usia dengan rentang usia 60-69 tahun sebanyak 4 orang $(10.5 \%)$ dari 38 responden.

\section{Tekanan Darah Sebelum dan Sesudah Dilakukan Terapi Bekam}

Tabel 2. Distribusi responden nilai rata-rata tekanan darah sistol dan diastole sebelum terapi bekam pada pasien hipertensi di Klinik BRC pasar minggu Jakarta 2016.

\begin{tabular}{|c|c|c|c|}
\hline $\begin{array}{l}\text { Tekanan darah } \\
\text { sistol \& diastol } \\
\text { sebelum di terapi } \\
\text { bekam }\end{array}$ & $\mathbf{N}$ & Mean & SD \\
\hline Tekanan darah sistol & 38 & 160,53 & 20,475 \\
\hline $\begin{array}{l}\text { Tekanan darah } \\
\text { diastol }\end{array}$ & 38 & 101,32 & 11,058 \\
\hline
\end{tabular}


Berdasarkan tabel diatas menunjukkan rata-rata tekanan darah sistol sebelum dilakukan terapi bekam menunjukkan nilai rata-rata sebesar 160,53 dengan standar deviasi 20,475. Sedangkan, rata-rata tekanan darah diastol sebelum dilakukan terapi bekam menunjukkan nilai rata-rata sebesar 101,32 dengan standar deviasi 11,058. Hasil di atas selanjutnya dibandingkan dengan tabel setelah dilakukan terapi bekam dengan cara dibandingkan, apakah terjadi perubahan nilai mean.

Tabel 3. Distribusi responden nilai rata-rata tekanan darah sistol dan diastole sesudah terapi bekam pada pasien hipertensi di Klinik BRC pasar minggu Jakarta 2016.

\begin{tabular}{lccc}
\hline $\begin{array}{l}\text { Tekanan darah } \\
\text { sistol \& diastol } \\
\text { sesudah di terapi } \\
\text { bekam }\end{array}$ & N & Mean & SD \\
\hline Tekanan darah sistol & 38 & 153,16 & 20,454 \\
$\begin{array}{l}\text { Tekanan darah } \\
\text { diastol }\end{array}$ & 38 & 96,89 & 11,986 \\
\hline
\end{tabular}

Berdasarkan tabel diatas menunjukkan rata-rata tekanan darah sistol sesudah dilakukan terapi bekam menunjukkan nilai rata-rata sebesar 153,16 dengan standar deviasi 20,454. Sedangkan, rata-rata tekanan darah diastol sesudah dilakukan terapi bekam menunjukkan nilai rata-rata sebesar 96,89 dengan standar deviasi 11,986. Dari hasil tabel 5.2 dan tabel 5.3 didapatkan hasil bahwasanya terjadi perubahan terhadap tekanan darah ketika diberikan intervensi terapi bekam dengan melihat nilai mean.

\section{Analisis Bivariat}

Tabel 4. Pengaruh terapi bekam terhadap penurunan tekanan darah pada pasien hipertensi di Klinik BRC pasar minggu Jakarta 2016.

\begin{tabular}{llcccc}
\hline No & & N & Mean & SD & $\begin{array}{c}\boldsymbol{P} \\
\text { Value }\end{array}$ \\
\cline { 1 - 4 } 1. & $\begin{array}{l}\text { Sistol } \\
\text { sebelum }\end{array}$ & 38 & 160,53 & 20,475 & \\
\cline { 1 - 4 } 2. & $\begin{array}{l}\text { Sistol } \\
\text { sesudah }\end{array}$ & 38 & 153,16 & 20,454 & 0.000 \\
\cline { 1 - 4 } 3. & $\begin{array}{l}\text { Diastol } \\
\text { sebelum }\end{array}$ & 38 & 101,32 & 11,058 & 0,000 \\
\cline { 1 - 4 } 4 & $\begin{array}{l}\text { Diastol } \\
\text { sesudah }\end{array}$ & 38 & 96,89 & 11,986 & \\
\hline
\end{tabular}

Berdasarkan tabel diatas menggunakan uji wilcoxon menunjukkan bahwa terdapat perbedaan tekanan darah (sistol dan diastol) sebelum dan sesudah di berikan intervensi terapi bekam. Rata-rata tekanan darah sistol setelah dilakukannya terapi bekam memiliki nilai rata-rata 153,16 , dengan standar deviasi 20,454. Sedangkan rata-rata tekanan darah sistol sebelum dilakukan terapi bekam menunjukkan nilai rata-rata sebesar 160,53, dengan standar deviasi 20,475. Dari perbandingan nilai rata-rata tekanan darah sistol sebelum dan sesudah berarti telah terjadi penurunan tekanan darah sistol pada pasien hipertensi yang melakukan terapi bekam.

Selanjutnya rata-rata pengaruh terapi bekam terhadap penurunan tekanan darah diastol setelah dilakukannya terapi bekam memiliki nilai rata-rata 101,32, dengan standar deviasi 11,058. Sedangkan rata-rata tekanan darah diastol sebelum dilakukan terapi bekam menunjukkan nilai rata-rata sebesar 96,89, dengan stadar deviasi 75. Dari perbandingan nilai rata-rata tekanan darah diastol sebelum dan sesudah berarti telah terjadi penurunan tekanan darah diastol pada pasien hipertensi yang melakukan terapi bekam. Dari hasil analisa bivariat menggunakan uji wilcoxon didapatkan nilai $p$ value tekanan darah sistol dan diastol sebesar 0,000 sehingga dapat dinyatakan bahwa ada pengaruh terapi bekam terhadap penurunan tekanan darah pada pasien hipertensi karena nilai $p$ value $<0,05$.

\section{Pembahasan}

\section{Karakteristik Responden}

\section{Usia}

Responden pada penelitian ini adalah perempuan yang memiliki penyakit hipertensi. Usia responden di Klinik BRC Pasar Minggu didapatkan data bahwa rentang usia 30-39 tahun sebanyak 12 orang (31.5\%), usia 40-49 tahun sebanyak 14 orang $(36,8 \%)$, usia $50-59$ tahun sebanyak 8 orang (21\%), usia 60-69 tahun sebanyak 4 orang $(10,5 \%)$ dari 38 orang responden. Hal ini sejalan dengan penelitian Yulis yang mengatakan bahwa tekanan darah akan semakin meningkat dengan bertambahnya usia, mencapai puncaknya pada pubertas kemudian cenderung menurun. Pada lanjut usia elastisitas arteri menurun dan arteri menjadi kaku. Hal ini meningkatkan tekanan sistolik karena dinding pembuluh darah secara fleksibel tidak mampu retraksi maka tekanan diastolik menjadi lebih tinggi. 


\section{Tekanan Darah Sebelum dan Sesudah Dilakukan Terapi Bekam}

Hasil analisa univariat mengenai perubahan tekanan darah sistol dan diastol sebelum diberikannya terapi bekam yaitu sistol 160,53 dengan standar deviasi 20,475. Hasil ini hampir sejalan dengan penelitian yang dilaksanakan Kusyati (2014) yang berjudul pengaruh arah putaran jarum bekam basah terhadap tekanan darah penderita hipertensi yaitu 165 dengan standar deviasi 13,542 pada arah putaran jarum kanan dengan 10 responden. ${ }^{8}$ Penelitian serupa juga diteliti oleh Noor Akbar (2013) dengan 40 responden dengan memiliki mean $157,38 .{ }^{9}$

Tekanan darah sistol sesudah diberikan intervensi bekam menjadi 153,16 dengan standar deviasi 20,454. Terjadi penurunan sistol dari 160,53 menjadi 153,16 terjadi selisih 7,37. Penelitian ini hampir serupa dengan penelitian yang dilakukan Azhari (2015) yang berjudul pengaruh terapi pijat refleksi kaki terhadap tekanan darah pada penderita hipertensi terjadi penurunan mean tekanan darah sistol sebesar $6,29 \mathrm{mmHg}$ dengan standar deviasi 5,07. ${ }^{10}$ Penelitian serupa juga diteliti oleh Akbar (2014) di Semarang dengan hasil rata-rata angka sistolik tekanan darah pada pasien hipertensi sebelum dan sesudah di lakukan terapi bekam adanya penurunan dari 157,38 menjadi $148,25 .^{9}$

Tekanan darah diastol sebelum dilakukannya intervensi bekam yaitu 101,32 dengan standar deviasi 11,058. Hasil penelitian sejalan dengan Mustika (2012) dengan hasil rata-rata penurunan tekanan darah diastolik sebelum terapi bekam 94,50 dengan standar deviasi $10,817 .{ }^{11}$

Tekanan darah diastol sesudah diberikan intervensi bekam menjadi 96,89 dengan standar deviasi 11,986. Terjadi penurunan dari nilai mean 101,32 menjadi 96,89 dengan selisih 4,43. Hal ini serupa dengan penelitian yang dilakukan Mustika (2012) dengan hasil rata-rata penurunan tekanan darah diastol sebelum dan sesudah terapi bekam 94,50 menjadi 89,60 dengan standar deviasi 10,923. ${ }^{11}$

Mekanisme penyembuhan bekam pada hipertensi didasarkan atas teori aktivasi organ, dimana bekam akan mengaktivasi organ yang mengatur aliran darah seperti hati, ginjal dan jantung agar organ-organ ini tetap aktif dalam mengatur peredaran darah sehingga tekanan darah tetap terjaga. Selain itu bekam juga berusaha menyeimbangkan secara alamiah bila ada tekanan darah yang meningkat. Dengan memilih titik yang tepat, maka bekam bisa membantu penanganan hipertensi. Efek terapi bekam terhadap hipertensi diantaranya: bekam berperan menenangkan sistem saraf simpatik (simpatic nervous system). Pergolakan pada sistem saraf simpatik ini menstimulasi sekresi enzim yang berperan sebagai sistem angiotensin rennin. Setelah sistem ini tenang dan aktivitasnya berkurang tekanan darah akan turun. Bekam berperan menurunkan volume darah yang mengalir di pembuluh darah sehingga mengurangi tekanan darah. ${ }^{5}$

\section{Pengaruh Terapi Bekam Terhadap Penurunan Tekanan Darah Pada Pasien Hipertensi di Klinik BRC Pasar Minggu.}

Hasil analisa bivariat dengan menggunakan uji normalitas menggunakan uji Shapiro-wilk mendapatkan nilai signifikan Shapiro-wilk variabel sistol sebelum $(0,000)$, diastol sebelum $(0,025)$, sistol sesudah $(0,003)$, diastol sesudah $(0,288)$. Berdasarkan keterangan di atas maka dapat disimpulkan data sebelum dan sesudah diberikan intervensi terapi bekam merupakan distribusi data tidak normal yaitu nilai $p$ value $<0,05$ sedangkan data normal memiliki nilai $p$ value $>0,05$. Lalu dilanjutkan dengan menggunakan uji wilcoxon pada sistol dan diastol, nilai $p$ value menunjukkan $<0,000$ yang berarti nilai $p$ value $<0,05$, maka hipotesa nol ditolak yaitu ada pengaruh terapi bekam terhadap penurunan tekanan darah setelah dilakukan bekam. Hal serupa juga didapatkan pada penelitian oleh Mustika (2012) yaitu Pengaruh terapi bekam terhadap tekanan darah pada pasien hipertensi di klinik de besh centre arrahman dan rumah sehat sabbihisma kota padang pada tekanan darah sistol dengan nilai $p$ value adalah 0,000 untuk sistolik dan 0,003 untuk diastolik $(p$ value < 0,05), maka terdapat pengaruh yang signifikan terhadap tekanan darah sistolik dan diastolik pada pasien hipertensi. ${ }^{11}$ Penelitian lainnya oleh Kusyai (2014) tentang pengaruh arah putaran jarum bekam basah terhadap tekanan darah penderita hipertensi di Kedung Mundu Semarang mendapatkan nilai $p$ value arah jarum kiri sistol dan diastol $=0,000$ dan 0,000 , sedangkan nilai $p$ value arah putaran jarum kanan sistol dan diastol $=0,009$ dan $0,000 .{ }^{8}$ Dapat disimpulkan ada pengaruh arah putaran jarum bekam terhadap tekanan darah pada pasien hipertensi. 
Hasil penelitian menunjukkan bahwa ada pengaruh terapi bekam terhadap tekanan darah yaitu terjadinya penurunan tekanan darah sistol dan diastol. Apabila dilakukan pembekaman pada satu poin maka kulit (kutis), jaringan bawah kulit (subkutis), fasia, dan otot akan terjadi kerusakan dari mast cell atau lain-lain. Akibat kerusakan ini akan dilepaskan beberapa zat seperti serotonin, histamine, bradikinin, slowreacting substance (SRS) serta zat lain yang belum diketahui. Zat-zat ini menyebabkan terjadinya dilatasi kapiler dan arteriol serta flare reaction pada daerah yang dibekam. Dilatasi kapiler juga dapat terjadi di tempat yang jauh dari tempat pembekaman ini menyebabkan terjadinya perbaikan mikrosirkulasi pembuluh darah. Akibatnya timbul efek relaksasi (pelemasan) otot-otot yang kaku serta akibat vasodilatasi umum akan menurunkan tekanan darah secara stabil. ${ }^{8}$

Efek bekam terhadap hipertensi diantaranya, bekam berperan menenangkan sistem saraf simpatik (simpatic nerveous system). Pergolakan pada sistem saraf simpatik ini menstimulasi sekresi enzim yang berperan sebagai sistem angiotensin rennin. Setelah sistem ini tenang dan aktivitasnya berkurang tekanan darah akan turun. Bekam berperan menurunkan volume darah yang mengalirkan darah di pembuluh darah sehingga mengurangi tekanan darah. ${ }^{5}$ Bekam mengendalikan kadar hormon aldosteron sehingga mengendalikan tekanan darah pula. Zat nitrat oksida (NO) berperan dalam vasodilatasi sehingga menyebabkan turunnya tekanan darah. Bekam mengendalikan tekanan hormone aldosterone sehingga mengendalikan tekanan darah. Bekam berperan menstimulasi reseptorreseptor khusus yang terkait dengan penciutan dan peregangan pembuluh darah (baroreseptor) sehingga pembuluh darah bisa merespon berbagai stimulus dan meningkatkan kepekaannya terhadap faktor-faktor penyebab hipertensi. ${ }^{5}$

Peneliti berasumsi bahwasanya terapi bekam yang diberikan kepada pasien hipertensi memiliki pengaruh yang bermakna pada tekanan darah darah sistolik dan diastolik pasien hipertensi sebelum dan sesudah terapi bekam. Bekam juga dapat dijadikan pengobatan alternatif bagi masyarakat yang memiliki penyakit hipertensi untuk menggunakan pengobatan terapi bekam dengan rutin dan menjaga pola makan serta menghindari stres sebagai upaya penurunan tekanan darah.

\section{Kesimpulan}

Kesimpulan dari hasil penelitian didapatkan bahwa telah terjadi perubahan sistolik dan diastolik pada nilai mean yang berarti terjadi penurunan tekanan darah setelah di terapi bekam. Dan ada pula pengaruh terapi bekam terhadap tekanan darah setelah dilakukan bekam dengan menggunakan uji wilcoxon pada sistol dan diastol menunjukkan terjadi pengaruh terhadap tekanan darah setelah diberikan intervensi terapi bekam.

\section{Saran}

Peneliti menyarankan kepada pelayanan kesehatan agar selalu menjaga kesterilan terhadap pelaksanaan pengobatan bekam serta memberikan penyuluhan kepada penderita hipertensi tentang mafaat terapi bekam sebagai pengobatan alternatif untuk pasien hipertensi.. Peneliti menyarankan kepada seluruh tenaga pendidik khususnya dosen keperawatan STIKIM untuk dapat menjadikan terapi bekam sebagai bahan perkuliahan bahwasanya masih banyak lagi manfaat yang bisa didapatkan pada terapi bekam sehingga mahasiswa bisa mempelajari cara melakukan pengobatan terapi bekam.

Harapan untuk peneliti selanjutnya agar dapat dijadikan sebagai tambahan informasi untuk mengembangkan penelitian lebih lanjut dengan jumlah responden yang lebih banyak dan dalam pemeriksaan post test dilakukan saat pasien datang bekam berikutnya, juga diharapkan hasil penelitian ini dapat dijadikan sebagai sumber rujukan oleh peneliti berikutnya dalam melakukan penelitan tentang pengobatan alternatif lain bagi penderita hipertensi.

\section{Daftar Pustaka}

1. Dalimartha. Care your self hipertensi. Depok: Penerbit penebar plus; 2008.

2. Kemenkes RI. Riset kesehatan dasar. Kementrian Kesehatan Republik Indonesia, Jakarta; 2013.

3. Hikayati. Penatalaksanaan non farmakologis terapi komplementer sebagai upaya untuk mengatasi dan mencegah komplikasi pada penderita hipertensi primer di kelurahan indralaya mulya kabupaten ogan ilir. Jurnal Pengabdian Sriwijaya, Indonesia; 2013.

4. Ridho, Achmad Ali. Bekam sinergi: rahasia sinergi pengobatan nabi, medis modern, dan tradisional chinese medicine. Solo: Aqwamedika ; 2012. 
5. Sharaf, Ahmad Razak. Penyakit dan terapi bekamnya. Surakarta: Thibbia, Surakarta; 2012.

6. Prof. Dr. Sugiyono. Statistika untuk penelitian. Bandung: Alfabeta, Bandung; 2007.

7. Notoatmodjo, Prof. Dr. Soekidjo. Metodologi penelitian kesehatan. Jakarta: Rineka Cipta; 2012.

8. Kusyati. Pengaruh arah putaran jarum bekam basah terhadap tekanan darah penderita hipertensi di kedung mundu semarang. Jurnal STIKES Karya Husada, Semarang; 2014.

9. Noor Akbar. Pengaruh bekam basah terhadap kolesterol dan tekanan darah pada pasien hipertensi di semarang. Jurnal Media Medika Muda, Semarang; 2013.

10. Rindang Azhari Rezky, dkk. Pengaruh terapi pijat refleksi kaki terhadap darah pada penderita hipertensi primer. Jurnal Universitas Riau, Riau; 2015.

11. Fera Mustika. Pengaruh terapi bekam terhadap tekanan darah pada pasien hipertensi di klinik de besh centre arrahman dan rumah sehat sabbihisma kota padang tahun 2012. Artikel Ilmiah, Padang; 2012.

12. PURNAMA, Agus; SALEH, Rachmad. Perbedaaan Pola Diet dan Stres terhadap Hipertensi Di Rumah Sakit PMI Bogor Tahun 2016. Jurnal Ilmiah IImu Keperawatan Indonesia, 2017, 7.04: 313-321 